\title{
Integrated Crop and Livestock Planning of a Minor Irrigation Command of Dhenkanal District by Linear Programming Approach
}

\author{
D. Paramjita ${ }^{1^{*}}$, B. Panigrahi ${ }^{2}$, J.C. Paul ${ }^{2}$ and N. Sahoo ${ }^{2}$ \\ ${ }^{1}$ Krishi Vigyan Kendra, Jagatsinghpur, OUAT, Bhubaneswar - 751003, Odisha, India \\ ${ }^{2}$ Department of Soil \& Water Conservation Engineering, CAET, OUAT, \\ Bhubaneswar - 751003, Odisha, India
}

*Corresponding author

\begin{tabular}{l} 
K e y w o r d s \\
$\begin{array}{l}\text { Minor irrigation project, } \\
\text { Linear programming, } \\
\text { Profit maximization, } \\
\text { Production maximization, } \\
\text { Investment minimization }\end{array}$ \\
Article Info \\
$\begin{array}{l}\text { Accepted: } \\
\text { xx September } 2018 \\
\text { Available Online: } \\
\text { xx October } 2018\end{array}$ \\
\hline
\end{tabular}

A B S T R A C T

The pace of irrigation development in independent India has been rapid and the contribution of minor irrigation system is around $41.85 \mathrm{M}$ ha. Unfortunately command area planning for the major irrigation projects has received sufficient attention and various methodology have been developed for optimal water use planning but no such effort has been made for the minor irrigation systems. Although the methodologies are similar for both types of commands there will be a change in approach due to change in level of planning which necessitates a need to develop an approach for command area planning of minor irrigation projects incorporating factors which affect the micro level planning. In this paper the linear programming model was used and the problem was solved through LINDO software for integrated crop and livestock planning in Gunduraposi MIP located in Dhenkanal district of Odisha. It is seen that while considering maximisation of profit the area under rice crop was $58.7 \%$ of the command area where as in case of maximising of production the same rice crop came around $62 \%$ of command area. In case of minimisation of investment on the rice crop, it is around $56 \%$ of command area. Profit was increased by $9 \%$ and $3.22 \%$ in production maximization and Net Return maximization model compared to Investment minimization model respectively.

\section{Introduction}

Agriculture plays a vital role in Indian Economy and more than $70 \%$ of the Indian population are directly or indirectly involved in agriculture. To meet the food and fodder requirement of growing population (both human and livestock), it is necessary to bring more area under cultivation. In addition to increase in production, special attention has to be given for increase in farmers' income. So crop component along with livestock planning has to be done for augmenting the production and increasing the farmers' income. The planning must consider essential thematic areas like increase in culturable command area, crop diversification, optimum utilization of available water and other resources. But due to Urbanization and strong reluctance to disturb natural environments it is difficult to bring the additional area under cultivation. The existing cropping pattern remains same for many years and may not utilize resources up to maximum economic efficiency. 
Therefore, it is important to optimize the available land and water resources for achieving maximum production with minimum investment. Linear programming model can handle a large number of constraints and thus, is an effective tool to aid in the optimization process.A best cropping pattern suitable to agroclimatic, socioeconomic and irrigation potential of the command area is very essential for a minor irrigation project.

\section{Materials and Methods}

The present study was done in command area of Gunduraposi Minor Irrigation Project (latitude $20^{\circ} 43^{\prime} 40^{\prime \prime} \mathrm{N}$, Longitude $-85^{\circ} 48^{\prime}$ 40" E) coming under Mid Central Table Land zone of Dhenkanal district in Odisha.

The soil type of the command area is sandy loam. Base line data of the minor irrigation project are, Full Reservoir Level-93.00 m, Dead Storage Level-88.70 m, Maximum Water Level-94.20 m, Catchment Area 22.02sq.km, Length of Earthen Dam-1100 m, Maximum Height of Dam-11.00 m, Length of Left Main Canal-5100 m, Length of Right Main Canal-4900 m, Gross Command area1012 ha, Culturable Command Area-817ha.

The base line data of the command area are Total Number of Household-2076, Number of villages-03, Total Population-9361, Marginal Farmer (\%)-58.87, Small Farmer (\%)-37.10, Medium farmer(\%)-3.82, Large Farmer(\%)0.21 . The command area of the project has several features common to many similar areas in the state of Odisha, Bihar, Jharkhand, Madhy Pradesh etc. Some of the important characteristics peculiar to backward areas like the Gunduraposi Command area are:

Dependence of the population on traditional agriculture practices and minor forest produces.
Seasonal rainfall

Poor education and skill level of the population

Low income level

Fragmented land holding and large number of marginal farmers and landless labourers

\section{Malnutrition}

High unemployment level of the workforce who have skill and experience in traditional agriculture practices only.

Affinity to particular food habits and sentimental considerations to raise the staple food requirements from the land owned by the farmer

Availability of skill in small scale dairy and poultry farming

Taking into account the typical characteristics of the command area, a developmental plan must consider the following possibilities

Increasing the land productivity through more intensive cropping and use of modern agriculture practices

Utilization of full irrigation potential and proper allocation of limited water resources to crops.

Maximum use of available labour force in the agriculture, animal husbandry and poultry etc. as strategy for employment generation. Ensuring availability of fodder, animal feed and poultry feed

Adopting a cropping pattern that meets both the economic and the crop affinity requirements. 
Ensuring the availability of inputs like seed, fertilizer and pesticides etc.

Ensuring a production pattern that meets the minimum nutritional needs of the command area population and thereby improving the health standard in the area.

Development of agro-based industries, if feasible

Ensuring an adequate return to the farmers.

Considering the above requirements, the first and foremost objective is to recommend a suitable plan which ensures the best allocation of both crops and livestock and simultaneously increase the income and minimizes the investment compared to existing practices of farmer.

\section{Step wise procedure for command area planning}

Collection of Socio-economic data of the command area - The information on socioeconomic aspects of the command area was collected during personal interview with groups of people from village through a questionnaire

Collection of hydrological data and analysis The daily rainfall and evaporation data of the command area were collected from O/O DDA, Dhenkanal for last 25years.In case of weekly rainfall analysis, the Modified Weibull's method is found to be the best one (Fig. 1), where as in evaporation probability distribution, Gumbell distribution is found be best one in $72 \%$ of cases.

Estimation of food (cereal, pulses, oilseeds and vegetable) and nutrition level - The food requirement of the command area population has been estimated for the projected population on the basis of balanced diet for a person during moderate type of work. While calculating the requirement, it is being assumed that 70 percent of the produce will be self-consumed and rest 30 percent will be sold in the market to meet their economic needs.

Economic analysis of different crops and animal husbandry (Milching Cow, Poultry): Package of practices of crop and livestock were collected from O/O the DDA, Dhenkanal and $\mathrm{O} / \mathrm{O} \mathrm{CDVO}$, Dhenkanal respectively. Estimation of the resource inventory of the area for resources like water, land, capital, fertilizer, labour availability etc.

Estimation of irrigation water requirement of different crops - It was estimated after analysis of pan evaporation and rainfall data. The surplus and deficit period analysis has been carried out to know the trend of deficit cycle in order to suggest the time of supplementary irrigation. At $70 \%$ probability of rainfall and $30 \%$ of probability of evaporation, the deficit period started. Irrigation requirement is estimated by the formula given below. (FAO, Irrigation and Drainage paper No. 24);

$\mathrm{IR}=\mathrm{EV}_{30} \times \mathrm{K}_{\mathrm{C}}+\mathrm{L}-\mathrm{RE}_{70}$

Where IR = Irrigation requirement of a crop in a particular week,

$\mathrm{EV}_{30}=$ Evaporation at 30 percent probability of occurrence in that week,

$\mathrm{RE}_{70}=$ Rainfall at 70 percent probability of occurrence in that week,

$\mathrm{L}=$ Percolation loss for that crop in that week,

$\mathrm{Kc}=$ Crop coefficient.

The net irrigation requirement in a particular season for a crop was estimated by adding weekly irrigation requirement of that crop. 
Preparation of a graph for surplus and deficit period of the year (week wise) at $70 \%$ probability of rainfall and at $30 \%$ probability of evaporation.

Keeping of as much area as possible under different vegetables and oilseed crops for crop diversification.

Preparation of a land allocation model with the objective of maximizing benefit, minimizing investment and maximizing production considering the constraints on land, labour, nutrition, water, cereal, pulses, vegetables, oilseed and affinity of the farmer with the help of a linear programming module.

\section{Mathematical formulations}

To recommend the plan three objective functions are formulated:

Maximization of Production:

$\operatorname{Max} \mathrm{Z}_{\mathrm{P}}=\sum_{i=1}^{18} \sum_{j=1}^{2} \sum_{k=1}^{2} P_{i j k} X_{i j k}$

Where,

$\mathrm{Z}_{\mathrm{P}}(\mathrm{X})=$ Value of the production function corresponding to a feasible solution $\mathrm{X}$

$\mathrm{P}_{\mathrm{ijk}}=$ Positive production from $\mathrm{i}^{\text {th }}$ crop (if feasible) in $\mathrm{jth}$ season for $\mathrm{kth}$ irrigation activity and zero otherwise

$\mathrm{X}_{\mathrm{ijk}}=$ Area of $\mathrm{i}^{\text {th }}$ Crop in $\mathrm{j}^{\text {th }}$ season for $\mathrm{k}^{\text {th }}$ irrigation activity

Net Return Maximization:

$\operatorname{Max} \mathrm{Z}_{\mathrm{R}}=\sum_{i=1}^{18} \sum_{j=1}^{3} \sum_{k=1}^{2} B_{i j k} X_{i j k}+\sum_{m=1}^{3} B_{m} Y_{m}$

Where,
$B_{i j k}=$ Net return from ith crop in jth season under kth irrigation condition, Rs/ha

$\mathrm{B}_{\mathrm{m}}=$ Benefit from animal type $\mathrm{m}$ per year (Rs)

$\mathrm{X}_{\mathrm{ijk}}=$ Area of land cultivated under ith crop in jth season under kth irrigation condition, ha

$\mathrm{Y}_{\mathrm{m}}=$ Number of animal type ' $\mathrm{m}$ '

$Z_{R}=$ Value of Net Return, Rs.

Investment Minimization:

$\operatorname{Min} \mathrm{Z}_{\mathrm{I}}=\sum_{i=1}^{19} \sum_{j=1}^{2} \sum_{k=1}^{2} C_{i j k} X_{i j k}+\sum_{m=1}^{3} C_{m} Y_{m}$

Where,

$\mathrm{C}_{\mathrm{ijk}}=$ Cost of cultivation of ith crop in $\mathrm{jth}$ season for kth irrigation activity (Rs/ha)

$\mathrm{X}_{\mathrm{ijk}}=$ Area of land cultivated under ith crop in jth season under kth irrigation condition, ha

$\mathrm{m}=$ A subscript $(\mathrm{m}=1,2,3)$ representing three types of animal i.e. $m=1$ for Cow, $m=2$ for Buffalo, $m=3$ for poultry

$\mathrm{C}_{\mathrm{m}}=$ Cost of rearing of animal of type $\mathrm{m}$ per year (Rs.)

$\mathrm{Y}_{\mathrm{m}}=$ Number of animal of type $\mathrm{m}$

Constraints

Area Constraint

$\sum_{i=1}^{19} \sum_{j=1}^{2} \sum_{k=1}^{2} x_{i j k} \leq A$

For Kharif Season

$\mathrm{X}_{0111}+\mathrm{X}_{0211}+\mathrm{X}_{0311}+\mathrm{X}_{1711} \leq 817.0$ (1) 
For Rabi Season

$\mathrm{X}_{0122}+\mathrm{X}_{0322}+\mathrm{X}_{0422}+\mathrm{X}_{0522}+\mathrm{X}_{0622}+\mathrm{X}_{0722}+$

$\mathrm{X}_{0822}+\mathrm{X}_{0922}+\mathrm{X}_{1022}+\mathrm{X}_{1122}+\mathrm{X}_{1222}+\mathrm{X}_{1322}+$

$\mathrm{X}_{1422}+\mathrm{X}_{1522}+\mathrm{X}_{1622}+\mathrm{X}_{1711} \leq 817.0$ (2)

Labour Constraint

$\sum_{i=1}^{19} \sum_{j=1}^{2} \sum_{k=1}^{2} L_{i j k} x_{i j k} \quad \sum_{m=1}^{3} L_{m j} Y_{m} \leq L_{j} \quad$ for $j=1,2,3$

Nutritional Constraint

Energy Constraint

$\sum_{i=1}^{18} \sum_{j=1}^{3} \sum_{k=1}^{2} E_{i j k} X_{i j k}+\sum_{m=1}^{3} E_{m} Y_{m} \geq E_{N}$

$E_{i j k}=$ Energy in kilo calories from ith crop on jth season for kth irrigation activity per ha

$E_{m}=$ Energy in calories from animal of type $\mathrm{m}$ per year (K cal)

$E_{N}=$ Total Energy requirement of the population per year Kcal

Protein Constraint

$\sum_{i=1}^{18} \sum_{j=1}^{3} \sum_{k=1}^{2} R_{i j k} X_{i j k}+\sum_{m=1}^{3} R_{m} Y_{m} \geq R_{N}$

$R_{i j k}=$ Protein from ith crop on $\mathrm{jth}$ season for kth irrigation activity per ha

$R_{m}=$ Protein from animal of type m per year $(\mathrm{Kg})$

$R_{N}=$ Total Protein requirement of the population per year $\mathrm{Kg}$
Iron Constraint

$\sum_{i=1}^{18} \sum_{j=1}^{3} \sum_{k=1}^{2} I_{i j k} X_{i j k}+\sum_{m=1}^{3} I_{m} Y_{m} \geq I_{N}$

$I_{i j k}=$ Iron from ith crop on $\mathrm{jth}$ season for kth irrigation activity per ha $(\mathrm{g})$

$I_{m}=$ Iron from animal of type m per year $(\mathrm{g})$

$I_{N}=$ Total Iron requirement of the population per year $(\mathrm{g})$

Calcium Constraint

$\sum_{i=1}^{18} \sum_{j=1}^{3} \sum_{k=1}^{2} C A_{i j k} X_{i j k}+\sum_{m=1}^{3} C A_{m} Y_{m} \geq C_{N}$

$C A_{i j k}=$ Calcium from ith crop on jth season for kth irrigation activity per ha (g)

$C A_{m}=$ Calcium from animal of type $\mathrm{m}$ per year $(\mathrm{g})$

$C_{N}=$ Total calcium requirement of the population per year $(\mathrm{g})$

Food Constraint

Cereal Constraint

$\sum_{i=1}^{18} \sum_{j=1}^{3} \sum_{k=1}^{2} P_{i j k} X_{i j k} \geq C_{E}+\sum_{m=1}^{3} P_{m} Y_{m}$

$P_{i j k}=$ Production of ith crop in jth season under kth irrigation condition, $\mathrm{q} / \mathrm{ha}$

$C_{E}=$ Cereal requirement of the population per $\operatorname{year}(\mathrm{q})$ 
$P_{m}=$ Cereal requirement of animal of type $m$ per year $(\mathrm{q})$

Pulse Constraint

$\sum_{i=1}^{18} \sum_{j=1}^{3} \sum_{k=1}^{2} P_{i j k} X_{i j k} \geq P_{E}$

$P_{E}=$ Pulse requirement of the population per year (q)

Potato Constraint

$\sum_{i=1}^{18} \sum_{j=1}^{3} \sum_{k=1}^{2} P_{i j k} X_{i j k} \geq P_{p}$

$P_{p}=$ Potato requirement of population per year $(q)$

Oilseed Constraint

$\sum_{i=1}^{18} \sum_{j=1}^{3} \sum_{k=1}^{2} P_{i j k} X_{i j k} \geq O_{E}$

$O_{E}=$ Total Oilseed requirement of population per year (qtl) (11)

Water Constraint

$W_{i j k}=$ Depth of water required ith crop on jth season for kth irrigation activity (ha.mm)

$$
\sum_{i=1}^{21} \sum_{k=1}^{2} W_{i j k} X_{i j k} \leq W_{j} \text { for } j=1,2 \text { and } 3
$$

$W_{j}=$ Total water availability in $\mathrm{jth}$ season (ha.mm)

\section{Affinity Constraint}

Due to strong affinity of the local people for Groundnut, it is expected that at least $15 \%$ of total Cultivable area in Kharif and $10 \%$ of net cultivable area in Rabi season should be earmarked for Groundnut cultivation.

Again $10 \%$ of total cultivable area in kharif should be taken for Arhar.

$$
\begin{aligned}
& X_{0311} \geq 0.15 A \text { for } j=1 \\
& X_{0322} \geq 0.10 A \text { for } j=2 \\
& X_{0211} \geq 0.10 A \text { for } j=1
\end{aligned}
$$

\section{Capital Constraint}

In developing countries like India, capital is the biggest constraint for command area planning. The capital available from all the source should not be less than the total expenditure involved.

$$
\sum_{i=1}^{20} \sum_{j=1}^{3} \sum_{k=1}^{2} C_{i j k} X_{i j k}+\sum_{m=1}^{3} C_{m} Y_{m} \leq R_{a}+R_{b}
$$

$C_{i j k}=$ Cost of cultivation of ith crop in $\mathrm{jth}$ season for kth irrigation activity (Rs.)

$C_{m}=$ Cost of rearing of animal of type m per year (Rs)

$R_{a}=$ Total capital available from own resources (Rs)

$R_{b}=$ Total capital available from bank (Rs.)

Animal Feed Constraint

Green Fodder: $17.5 \mathrm{X}_{1711}-36.50 \mathrm{Y}_{1}-54.75 \mathrm{Y}_{2}$ $\geq 0$ (16)

Straw: $66 \mathrm{X}_{0111}+70 \mathrm{X}_{0122}-18.25 \mathrm{Y}_{1}-18.25 \mathrm{Y}_{2} \geq$ 0 (17)

\section{Fertilizer Constraint}


For Nitrogen

$$
\begin{aligned}
& F_{0111}^{1} \mathrm{X}_{0111}+F_{0122}^{1} \mathrm{X}_{0122}+F_{0211}^{1} \mathrm{X}_{0211}+ \\
& F_{0311}^{1} \mathrm{X}_{0311}+\quad F_{0322}^{1} \mathrm{X}_{0322}+\quad F_{0422}^{1} \mathrm{X}_{0422}+ \\
& F_{0522}^{1} \mathrm{X}_{0522}+\quad F_{0622}^{1} \mathrm{X}_{0622}+\quad F_{0722}^{1} \mathrm{X}_{0722}+ \\
& F_{0822}^{1} \mathrm{X}_{0822}+F_{0922}^{1} \mathrm{X}_{0922}+F_{1022}^{1} \mathrm{X}_{1022}+ \\
& F_{1122}^{1} \mathrm{X}_{1122}+F_{1222}^{1} \mathrm{X}_{1222}+ \\
& F_{1422}^{1} \mathrm{X}_{1422}+ \\
& F_{1622}^{1} \mathrm{X}_{1622}+F_{171125 \mathrm{X}_{1711} \leq F^{1}}^{1} \\
& F_{1322}^{1} \mathrm{X}_{1322+} \\
& F_{1522}^{1} \mathrm{X}_{1522+}
\end{aligned}
$$

For Phosphorous

$$
\begin{array}{lcc}
F_{0111}^{2} \mathrm{X}_{0111}+ & F_{0122}^{2} \mathrm{X}_{0122}+ & F_{0211}^{2} \mathrm{X}_{0211}+ \\
F_{0311}^{2} \mathrm{X}_{0311}+ & F_{0322}^{2} \mathrm{X}_{0322}+ & F_{0422}^{2} \mathrm{X}_{0422}+ \\
F_{0522}^{2} \mathrm{X}_{0522}+ & F_{0622}^{2} \mathrm{X}_{0622}+ & F_{0722}^{2} \mathrm{X}_{0722}+ \\
F_{0822}^{2} \mathrm{X}_{0822}+ & F_{0922}^{2} \mathrm{X}_{0922}+ & F_{1022}^{2} \mathrm{X}_{1022}+ \\
F_{1122}^{2} \mathrm{X}_{1122}+ & F_{1222}^{2} \mathrm{X}_{1222}+\mathrm{X}_{1322}+ & F_{1422}^{2} \mathrm{X}_{1422}+ \\
F_{1522}^{2} \mathrm{X}_{1522}+ & F_{1622}^{2} \mathrm{X}_{1622}+F_{1711}^{2} \mathrm{X}_{1711} \leq F^{2}
\end{array}
$$

For Potash

$$
\begin{aligned}
& F_{0111}^{3} \mathrm{X}_{0111}+F_{0122}^{3} \mathrm{X}_{0122}+F_{0211}^{3} \mathrm{X}_{0211}+ \\
& F_{0311}^{3} \mathrm{X}_{0311}+F_{0322}^{3} \mathrm{X}_{0322}+ \\
& F_{0422}^{3} \mathrm{X}_{0422}+F_{0522}^{3} \mathrm{X}_{0522}+\quad F_{0622}^{3} \mathrm{X}_{0622}+ \\
& F_{0722}^{3} \mathrm{X}_{0722}+\quad F_{0822}^{3} \mathrm{X}_{0822}+\quad F_{0922}^{3} \mathrm{X}_{0922}+ \\
& F_{1022}^{3} \mathrm{X}_{1022}+\quad F_{1122}^{3} \mathrm{X}_{1122}+\quad F_{1222}^{3} \mathrm{X}_{1222}+ \\
& F_{1322}^{3} \mathrm{X}_{1322}+F_{1422}^{3} \mathrm{X}_{1422}+F_{1522}^{3} \mathrm{X}_{1522}+F_{1622}^{3} \mathrm{X}_{1622} \\
& +F_{1711}^{3} \mathrm{X}_{1711} \leq F^{3} \text { (19) }
\end{aligned}
$$

The above Linear programming module has been solved by LINDO Software.

\section{Results and Discussion}

Considering the objective of Maximization of Net return, Maximization of Production and
Minimization of investment, along with all the constraints, the area allocated to different crops in Kharif and Rabi season are given in the Table 1. The optimal food production for major crops of the command area i.e. Rice, Arhar, Groundnut, Greengram and Blackgram was found to be 31410 qtl, 1634 qtl, 3880.75qtl, 960qtl and 480qtl with investment of $25.06,2.85,8.43,1.856$ and 0.928 million rupees respectively. The net return from the above allocation was 23.2, 3.68, 4.63, 2.46 and 1.23 million rupees respectively.

From the Figure 2, it is observed that in case of Garlic investment is highest i.e. Rs.1,16,083/- whereas in case of Greengram and Blackgram, it is lowest i.e. Rs.23,200/-. Similarly the highest net return is found in Brinjal i.e. Rs.1,38,827/-and lowest return of Rs.27,055/- from Mustard.

It is observed from Table 1 that most of the crop area allocation is same in all the three objectives, which may be due to limited availability of water and investment. But in case of paddy and cabbage there is difference in allocation in all three objectives.

Probably Garlic did not find a place in allocation model due to higher investment. In case of poultry, maximum number is allocated in net return maximization and lowest in investment minimization was seen due to higher return in poultry.

Buffalo didn't figure in the model because of higher food and fodder requirement, whereas number of cows in all three objectives are same.

\section{Cereal production in LP model}

The cereal requirement of the command area population is 17,767.17qtl. In 'Net return maximization', cereal production is $30,024 \mathrm{qtl}$ and in 'investment minimization', it is 
28,332qtl and in 'maximization of production', it is 31,410qtl. Since cereal production in three models varies from 4.4 to 9.7 percent only, hence the decision maker can take any model according to investment. Cereal production is more than requirement in Dhenkanal district but still the decision maker can think of increasing cereal production as farmers sells 70 to 80 percent of their produce in Government regulated markets for better return as a result only 20 to $30 \%$ cereal is left which is not enough for his family and also for his poultry feed.

If cereal production is increased by $10 \%$ to prepare feed for poultry, then subsidy has to be given to cereal growers to make up their loss as they would get less land for other remunerative crop.

\section{Oilseed production}

Oilseed production in all three LP models are same i.e. 4038.25qtl. It is observed that the oilseed requirement of the population in the command area is fully met but due to absence of oilmills, majority of the produce is procured by private companies such as ITC and Godrej. Hence there is a need to further increase oilseed production exclusively for Poultry feed requirement so as to meet the protein requirement of the inhabitants of the command area from poultry. Also, oilseed production is an investment sensitive enterprise which requires more water that can be met from minor irrigation projects. Hence subsidy should be given for water resource development in the command area in the form of open well or tubewell.

Table.1 Crop area (ha) and Livestock (No) allocation by linear programming module

\begin{tabular}{|c|c|c|c|c|}
\hline SI No & $\begin{array}{l}\text { Name of crop } \\
\text { /Animal }\end{array}$ & $\begin{array}{l}\text { Maximization of } \\
\text { Production }\end{array}$ & $\begin{array}{l}\text { Maximization } \\
\text { of Net return }\end{array}$ & $\begin{array}{l}\text { Minimization } \\
\text { of Investment }\end{array}$ \\
\hline \multicolumn{5}{|c|}{ Kharif-Rainfed } \\
\hline 01. & Paddy & 507 & 480 & 465 \\
\hline 02. & Arhar & 81.7 & 81.7 & 81.7 \\
\hline 03. & Groundnut & 122.55 & 122.55 & 122.55 \\
\hline 04. & Cowpea & 104.28 & 104.28 & 104.28 \\
\hline \multicolumn{5}{|c|}{ Rabi-Irrigated } \\
\hline 01. & Paddy & 101 & 100.4 & 84.7 \\
\hline 02. & Groundnut & 81.7 & 81.7 & 81.7 \\
\hline 03. & Potato & 8.2 & 8.2 & 8.2 \\
\hline 04. & Brinjal & 20 & 20 & 20 \\
\hline 05. & Onion & 15 & 15 & 15 \\
\hline 06. & Cabbage & 10 & 11.84 & 10 \\
\hline 07. & Cauliflower & 10 & 10 & 10 \\
\hline 08. & Coriander & & & \\
\hline 09 & Garlic & & & \\
\hline 10. & Greengram & 80 & 80 & 80 \\
\hline 11. & Blackgram & 40 & 40 & 40 \\
\hline 12. & Mustard & 10.5 & 10.5 & 10.5 \\
\hline 13. & Horsegram & & & \\
\hline 14. & Cow & 100 & 100 & 100 \\
\hline 15. & Poultry & 1462 & 6063 & 150 \\
\hline 16. & Buffalo & 0 & 0 & 0 \\
\hline
\end{tabular}


Fig.1 Variation of rainfall in different weeks at different probabilities

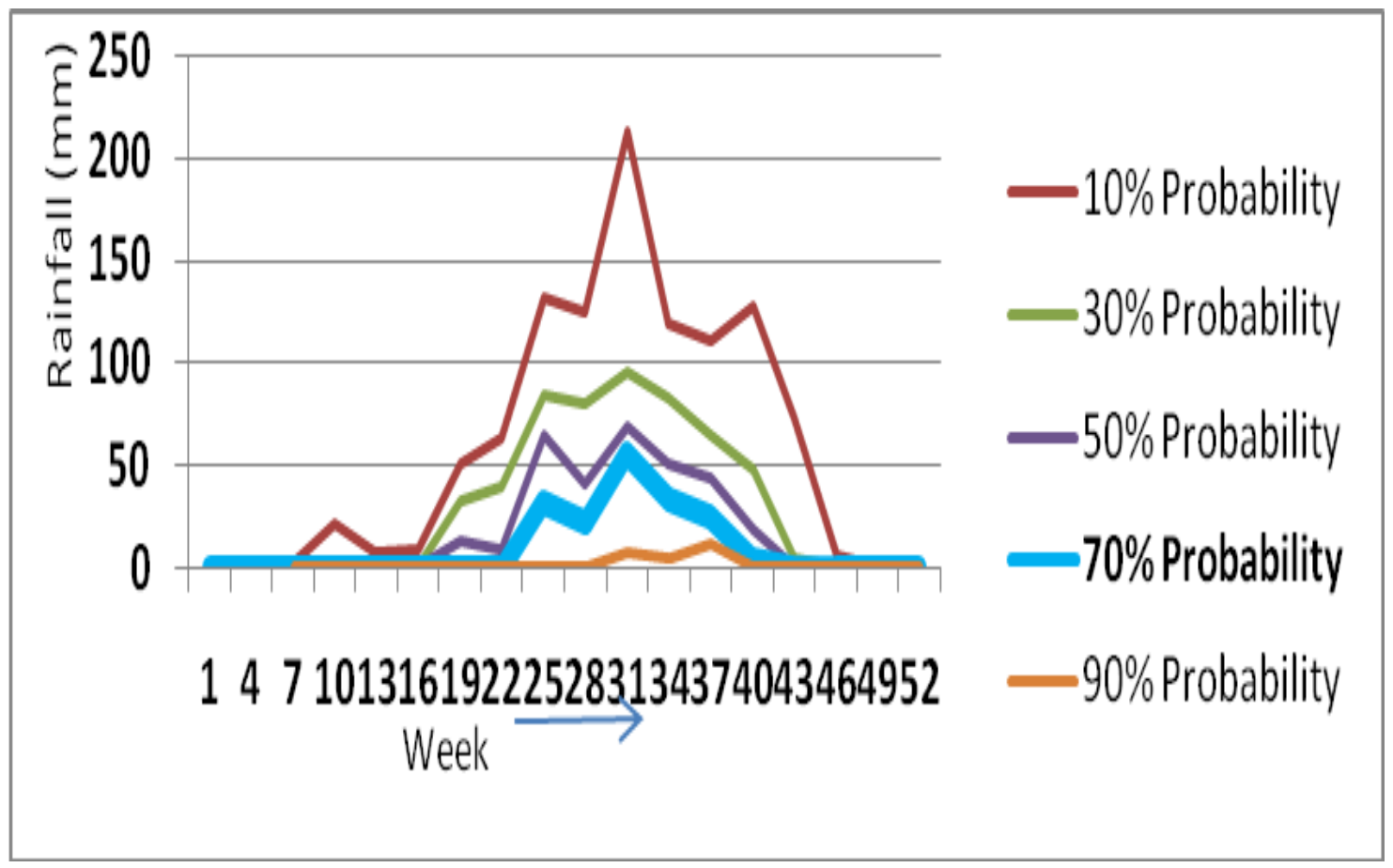

Fig.2 The investment and net return from different crops with standard package of practices

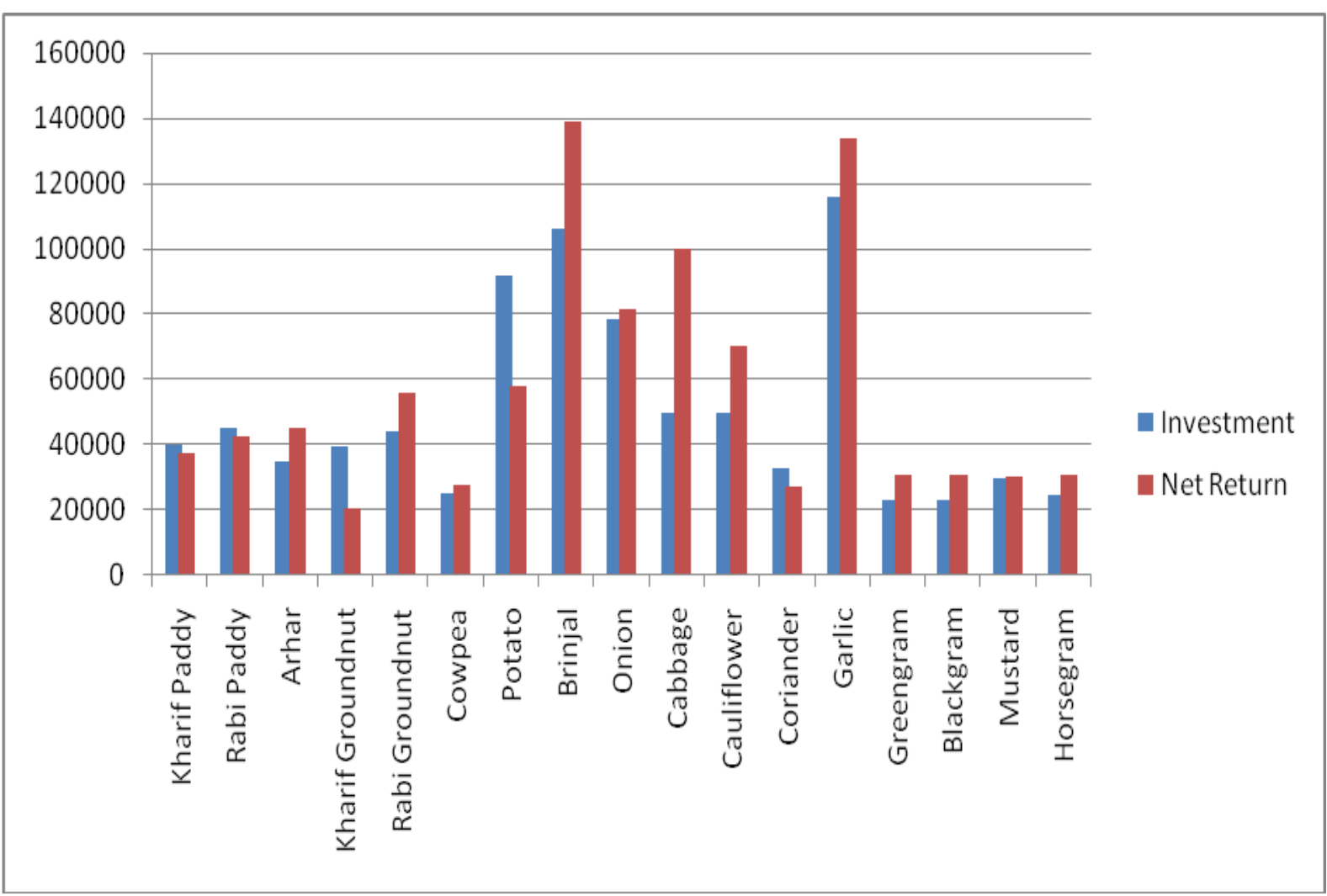


Fig.3 Graphical representation of production in case of existing command area and LP module optimizing objective function 'Maximizing Production' Maximizing Net Return' and

'Minimizing Investment'

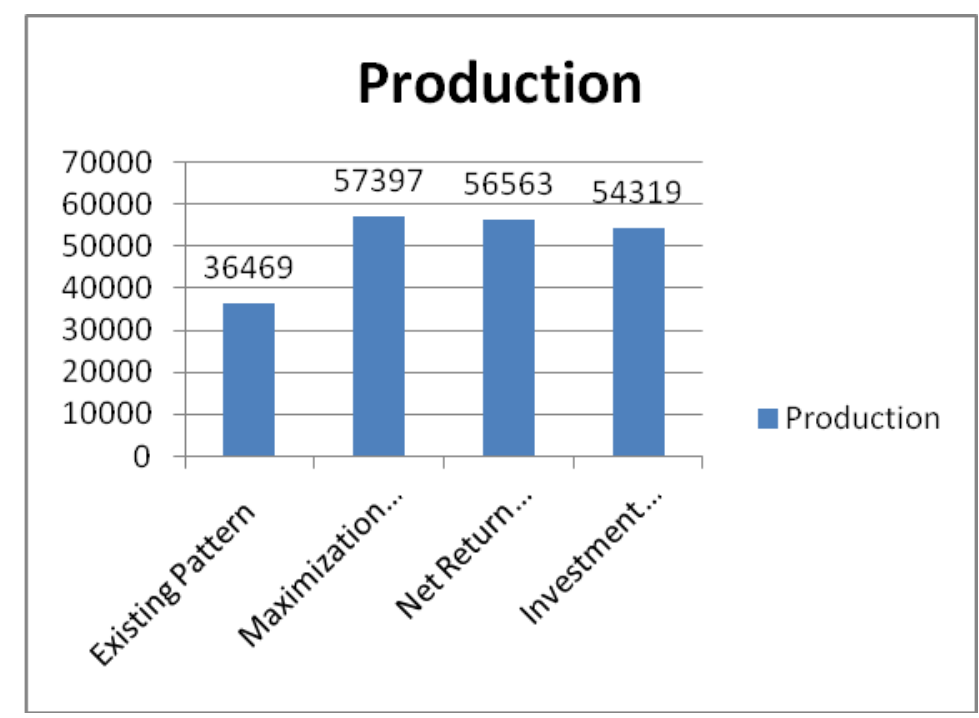

Fig.4 Graphical representation of net return and investment of the command area in case existing condition and LP module optimizing objective function 'Maximizing Production' Maximizing

Net Return' and 'Minimizing Investment'

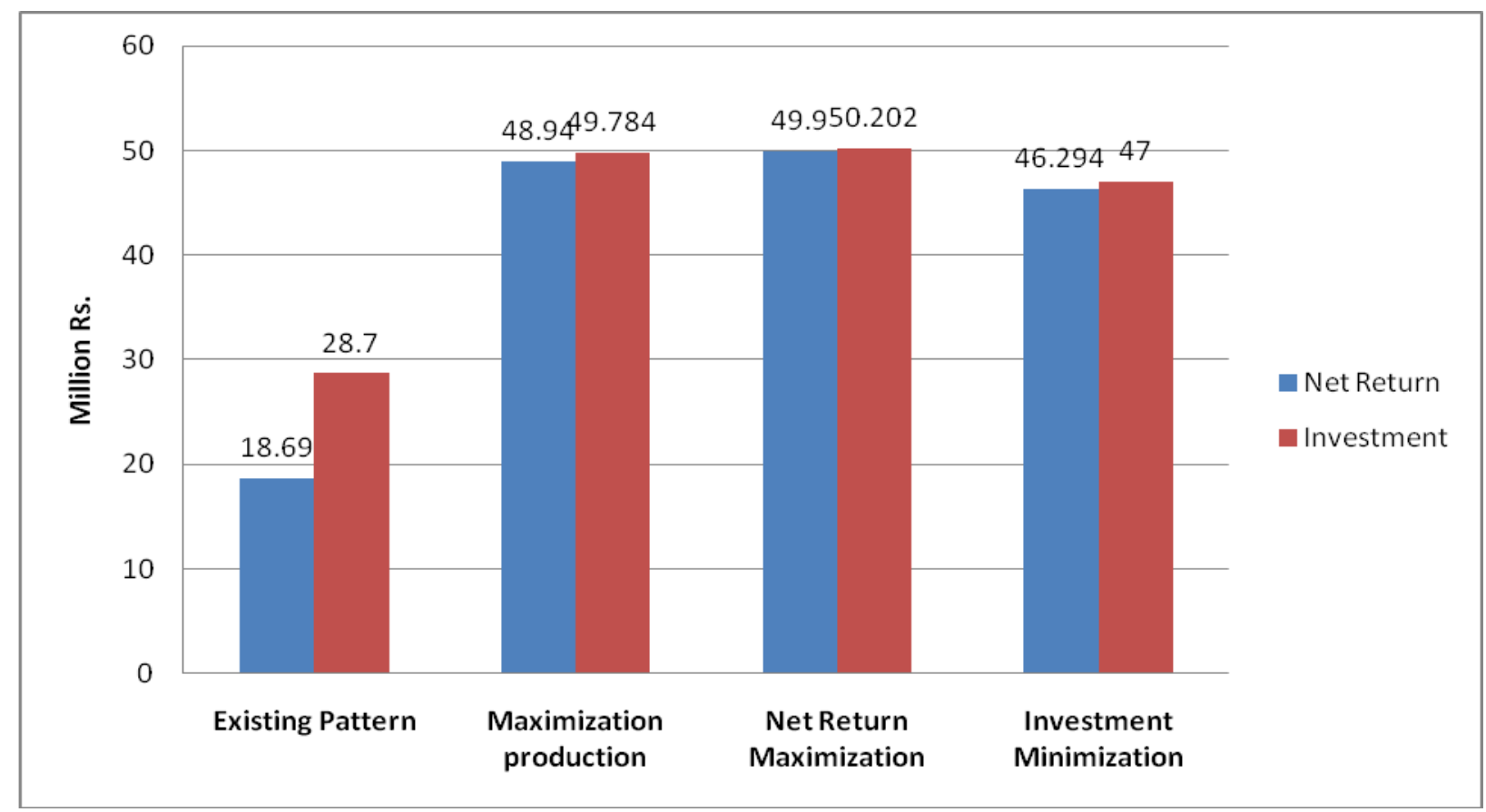

\section{Pulse production}

Requirement of pulse is low in the command area compared to production in all the three models i.e. 3074 quintals. So pulse area can be diverted towards oilseed production to meet the requirement of the command area population. 


\section{Vegetable production}

The command area under study became famous for vegetable production after the construction of minor irrigation project. Vegetable requirement of the population is 3416.765 qtl but the total vegetable production in three LP models are almost same i.e. 15000qtl.

Only in Net Return maximization model production is 15,522qtl. Therefore the Vegetable production is sufficient for projected population of the command area. Vegetable production is water sensitive and the minor irrigation projects provide adequate water for its profitable production.

\section{Potato production}

Through optimization of allocation, potato production and requirement reached 2050qtl. But since there is availability of cold storage in the districts farmers should be motivated for more potato production. Generally during summer and rainy season potato price is very high in Odisha i.e., 5 to 6 times more than the price during production. So increase in potato area will improve economy of the farmer. From Figure 3 it is seen that production potential is more than $57.4 \%$ compared to existing production. But if all the three LP models are compared, the production potential varies from $1.4 \%$ to $5.3 \%$. Hence all the models are excellent compared to existing crop model. Similarly, from Figure 4 it is clearly depicted that both net return and investment is $167 \%$ and $63.8 \%$ higher than existing pattern in net return maximization and investment minimization model respectively. Comparing three models, the net return varies from $2 \%$ to $7.2 \%$ in relation to net return maximization. Similarly, if investment is considered then it varies from $6.8 \%$ to $5.9 \%$ in net return maximization and production maximization model.
The entire paper discussed on rainfall probabilities, soil type of the command area, water requirement of different crops and animal, surplus and deficit period, economics of cost of cultivation of different crops and animals helped to develop an optimal solution for the area using water available from Minor Irrigation project and other sources subjected to labour, area, vegetable, energy, protein, affinities using 'LINDO' software for three models namely Maximisation of Net Return, maximisation of production and minimization of investment. In case of weekly rainfall analysis, the Modified Weibull's method is found to be the best, where as in evaporation probability distribution, Gumbel Maximum distribution is found be best in $72 \%$ of cases. Week no.29, 31 to 34 and $37\left(16^{\text {th }}\right.$ July to $9^{\text {th }}$ September) shows Surplus period of rainfall and other weeks are the deficit period. Rice crop predominates the command area with $62 \%$ area coverage in kharif season in all the three models. The net cultivable area increased by 22.4 percent in comparison to existing area coverage with the objective of production maximizing. In the present crop planning, conventional crops have been selected considering the farmers' interest. Cowpea crop has been introduced as a fodder crop to reduce the feed cost of the livestock. The net return maximization model gives the highest benefit cost ratio i.e. 2:1. All the above planned models are excellent and are recommended by the decision maker for adopting the different crop allocation. Results of LP model can help to achieve considerable conservation of water and capital resources. Additionally, the income generation of the farming system will also increase. The model has given an insight for the Decision maker to change the allocation of crop as per his schedule for increased cereal production, oilseed production and potato production. For doing this Decision Maker has to allow subsidy for other crops whose area allocation will be decreased. Finally the study shows 
that the linear programming based management models have the capability for optimal land-water-crop system planning in case of single criteria decision systems. Similar results were found by Biswas et al., (2005), Devi et al., (2013), Patel et al., (2017), Singh and Singh (1999), Singh et al., (2001) and Vivekanandan (2009) for optimization allocation of different resources in Linear, Fuzzy and Goal programming in different irrigation projects.

\section{Acknowledgements}

The authors acknowledge The Deputy Director Agriculture, Dhenkanal and The Chief District Veterinary Officer, Dhenkanal for providing necessary hydrological data and package of practice of different crops and livestocks. The authors also acknowledge The Department of Soil and Water Conservation Engineering, College of Agricultural Engineering and Technology, OUAT, Bhubaneswar for providing necessary infrastructural facilities to carry out the research works.

\section{References}

Biswas, A., and Pal, B.B. 2005.Application of Fuzzy Goal Programming technique to land use planning in Agricultural System. Omega. 33(5): 391-398.

Devi, S.B., Ranghaswami, M.V., Mayilswami, C. 2013. Optimization Technique for Conjuctive use and cropping pattern planning in Parambikulam- Aliyar - Palar basin of Coimbatore. International Journal of Agricultural Engineering. 6(1).

Patel, N., Thaker, M., Chaudhari, C. 2017. Agricultural land allocation to the Major crops through Linear Programming Model. International Journal of Science and Research. 6(4): 519-522.

Singh, A. K. and Singh, J. 1999. Production and benefit maximization through optimal crop planning-A case study of Mahi command. Indian Journal of Soil Conservation. 27(2): 152-157.

Singh, D. K, Jaiswal, C. S., Reddy, K. S., Singh, R. M., Bhandarkar, D. M. 2001. Optimum cropping pattern in a canal command area. Agricultural Water Management, 50: 1-8.

Vivekanandan, N. 2009. Maximization of net returns for upper Indravati Project using Goal Programming approach. Journal of Water Management: 17 (2).

\section{How to cite this article:}

Paramjita, D., B. Panigrahi, J.C. Paul and Sahoo, N. 2018. Integrated Crop and Livestock Planning of a Minor Irrigation Command of Dhenkanal District by Linear Programming Approach. Int.J.Curr.Microbiol.App.Sci. 7(10): 1567-1578.

doi: https://doi.org/10.20546/ijcmas.2018.710.176 